\title{
Late Pleistocene to Recent ostracod assemblages from the western Black Sea
}

\author{
IAN BOOMER ${ }^{1, *}$, FRANCOIS GUICHARD ${ }^{2} \&$ GILLES LERICOLAIS $^{3}$ \\ ${ }^{1}$ School of Geography, Earth \& Environmental Sciences, University of Birmingham Birmingham B15 2TT, UK \\ ${ }^{2}$ Laboratoire des Sciences du Climat et de l'Environnement (LSCE, CEA-CNRS-UVSQ) Avenue de la Terrasse, 91198 Gif sur Yvette, France \\ ${ }^{3}$ IFREMER, Centre de Brest, Géosciences Marines, Laboratoire Environnements Sédimentaires BP70, F-29280 Plouzané cedex, France \\ ${ }^{*}$ Corresponding author (e-mail: i.boomer@bham.ac.uk)
}

\begin{abstract}
During the last glacial phase the Black Sea basin was isolated from the world's oceans due to the lowering of global sea-levels. As sea-levels rose during the latest glacial and early Holocene period, the Black Sea was once again connected to the eastern Mediterranean via the Dardanelles-MarmaraBosporus seaway. In recent years, trace element and stable isotope analyses of ostracod assemblages have yielded important details regarding the hydrological evolution of the Black Sea during these events. Despite this focus on the geochemical signatures of the ostracods, little if any attention has been paid to the taxonomic composition of the ostracod assemblages themselves and there are notably few publications on the sub-littoral fauna of this important water body. We present a summary of the most abundant ostracod taxa of the Black Sea during the late glacial to early Holocene phase (dominated by the Candonidae, Leptocytheridae and Loxoconchidae) and chart their response to the subsequent environmental changes in the early Holocene with the pre-connection, low salinity 'lacustrine' fauna being replaced by one with a more Mediterranean aspect. Many of these taxa are illustrated using SEM for the first time, providing an important initial step in establishing taxonomic stability within Black Sea ostracod studies and noting faunal similarities with neighbouring areas, such as the Caspian Sea. J. Micropalaeontol. 29(2): 119-133, December 2010.
\end{abstract}

KEYWORDS: Ponto-Caspian, Black Sea, Ostracoda, Pleistocene, Holocene

\section{BACKGROUND}

The Black Sea is a large, deep-water epicontinental sea connected to the eastern Mediterranean Basin, and thereby the world's oceans, through a narrow and shallow series of corridors, the Dardanelles-Marmara-Bosporus seaway (Fig. 1). Today, there is an exchange between a lower and in-flowing warm, saline Mediterranean water and an upper out-flowing, cooler, fresher Black Sea water, the sea is now heavily stratified and is permanently dysaerobic at depth (Neretin et al., 2001). The mean salinity of the modern Black Sea is about $17 \%$ in most of the surface waters and as much as $23 \%$ in deep water. This situation was established during the early Holocene. During the last major glacial phase the Black Sea basin became isolated as the level of the eastern Mediterranean fell below that of the connecting pathway due to glacio-eustatic sea-level fall. Subsequently, as the global ice-sheets returned much of their water to the oceans, there was a period of significant post-glacial sea-level rise, the Black Sea and Mediterranean once again became connected during the early Holocene and the exchange of waters established. It is probable that this has occurred on a number of previous occasions during the Quaternary (Schrader, 1979).

The pattern of isolation followed by initial connection, then sea-level rise and subsequent stratification are recorded in the Black Sea sedimentary record. Ross et al. (1970) described the occurrence of three distinct units observed in the uppermost few metres of sediment cores recovered across the Black Sea basin which were dated using ${ }^{14} \mathrm{C}$ analysis of molluscs. The youngest sedimentary unit (Unit I, mid-Holocene to Recent) constitutes only a few tens of centimetres and displays very fine microlaminations of alternating light and dark layers. The lightcoloured layers are almost exclusively composed of monospecific assemblages of the coccolithophorid Emiliania huxleyi (see Giunta et al., 2007 and Oaie \& Melinte-Dobrinescu, 2009, for recent discussion). Major et al. (2002) further subdivided Unit III based on sedimentological and geochemical characteristics. On the continental shelf, Shcherbakov \& Babak (1979) subdivided the sedimentary sequence based upon the sedimentology and mollusc composition (i.e. Modiolus, Mytilus and Dreissena), which were subsequently correlated with deep-sea cores by Giunta et al. (2007).

The middle unit (Unit II, early to mid-Holocene), again only a few tens of centimetres thick, comprises dark, fine-grained sediments with high organic content, i.e. a sapropel, and represents the establishment of anoxic conditions, probably associated with enhanced surface productivity and stratification. The oldest unit (Unit III, late glacial) comprises fine-grained detrital sediments, generally light in colour but with occasional darklight alternations; this unit extended for many metres and represents a pre-connection, possibly 'lacustrine' phase with apparently well-ventilated bottom waters.

The precise timing, rate and flow-direction of the connection has been the subject of much discussion (Ryan et al., 1997; 2003; Ballard et al., 2000; Uchupi \& Ross, 2000; Aksu et al., 2002; Siddal et al., 2004; Yanko-Hombach et al., 2007; Giosan et al., 2009; Lericolais et al., 2009 and refs therein) and was popularized through the work of Ryan \& Pitman (1999). One of the major obstacles in unravelling the story of events has been the establishment of a robust chronology (Siani et al., 2000).

Recent studies have highlighted problems in interpreting radiocarbon dates obtained from the Black Sea with inconsistencies between dates on organic fractions and those of carbonate shells. Kwiecien et al. (2008) identified changing reservoir corrections depending on water depth of the sample material and the stratification status of the Black Sea at that time. During the glacial, low-level phase (or Black 'Lake' as they referred to it) the water column was well mixed, with a radiocarbon reservoir 


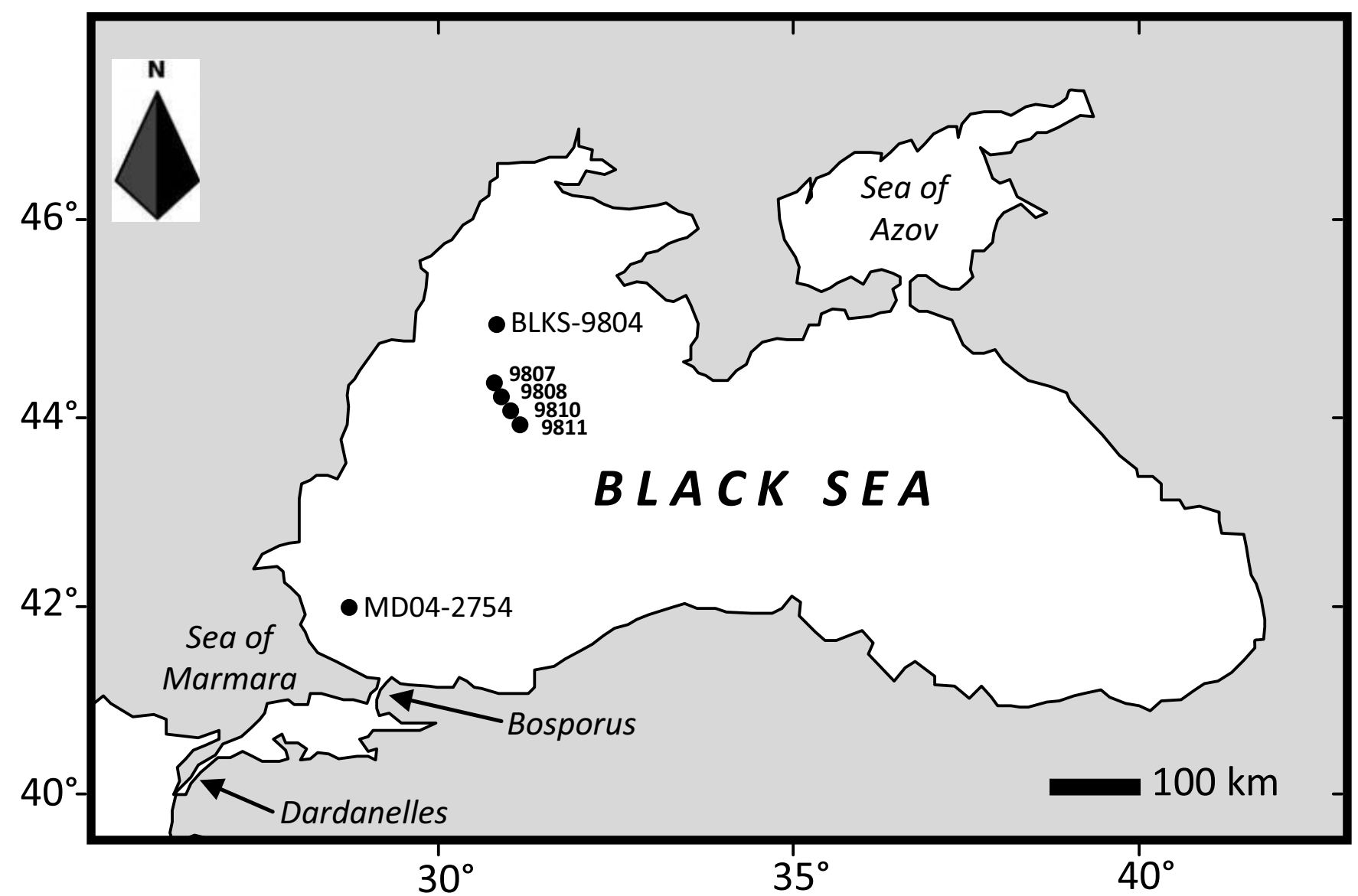

Fig. 1. Location map showing site of BLKS transect, NW Black Sea and Core MD04-2754 from the SW Black Sea.

age of about 1450 years throughout the Sea, which decreased to about 1000 years by the Bölling/Allerød interstadials, probably due to melt-water input, finally reducing to 400 years (almost normal marine values) in the post-connection period. Fontugne et al. (2009) showed that the ${ }^{14} \mathrm{C}$ activity of dissolved inorganic carbon (DIC) in the upper levels of the modern Black Sea are in equilibrium with the atmosphere and, therefore, no correction is necessary but that, at depth, the ${ }^{14} \mathrm{C}$ activity of DIC increases due to chemical and physical conditions in these stratified waters. They suggested that some of the large reservoir values observed previously may be associated with the action of chemautotrophic organisms in the deeper basins. Due to the problems associated with evaluating the reservoir age within the Black Sea (Fontugne et al., 2009), all dates given in this paper are uncalibrated ${ }^{14} \mathrm{C}$ ages; ongoing ${ }^{210} \mathrm{~Pb}$ studies will help to address such issues. The early Holocene flooding event (Unit III/Unit II transition) is now dated to around $8400{ }^{14} \mathrm{C}$ years BP and the Unit II/Unit I transition to about $3000{ }^{14} \mathrm{C}$ years BP.

\section{BLACK SEA OSTRACODA}

In a number of recent studies, ostracods have proven fundamental to achieving an understanding of the hydrological changes in the bottom waters of the Black Sea over the last $20 \mathrm{ka}$. They are the only benthic organisms with a significant fossil record, although they are generally absent from all environments within the current dysaerobic zone. Recent studies (Sergeeva, 2003) have shown that a significant soft-bodied meiobenthos still inhabits surficial sediments in deep-water parts of the basin, comprising taxa that have adapted from shallower depths and others that are endemic to the sulphidic zone. The environment should, therefore, be described as dysoxic rather than wholly anoxic. Trace-element chemistry and stable-isotope analyses of ostracod remains recorded in the sediments deposited during the last 15000 years have been used to elucidate the hydrological history of the Black Sea basin (Major et al., 2002; 2006; Bahr et al., 2005; 2006). None of these studies, however, has considered the ostracod faunal record in any detail and none has published images or taxonomic details of the faunas encountered. It is the goal of this paper to record and illustrate many of the key taxa that constitute the distinct 'Black Sea' fauna (many using scanning electron microscopy (SEM) for the first time) that dominated the benthic environment before the establishment of deep-water anoxia and that probably still persist at intermediate depths today.

Kaminski et al. (2002) provided information on the lateGlacial to Holocene foraminiferal record of the Sea of Marmara; however, foraminifera are very rare in the deeper-water sediments of the Black Sea investigated in this study, and the few occurrences noted are considered to be allochthonous, reworked downslope. Again, within the Sea of Marmara there is a strong halocline due to the inflowing Mediterranean and outflowing 
Black Sea waters and this has led to the establishment of low oxygen conditions in the deep-water parts of the Marmara (Kaminski et al., 2002). Nazik (2001) recorded diverse ostracod assemblages in the surface sediments of the Sea of Marmara from depths of $<72 \mathrm{~m}$. The fauna comprised taxa that were also recorded from similar environments in the Mediterranean. In this paper we show that the pre-connection deep-water, ostracod fauna of the Black Sea basin has closer taxonomic links with the 'paratethyan' fauna found in the Caspian Sea today and suggest that the same taxa are probably present today at intermediate water depths of the Black Sea basin, above the modern dysaerobia.

Following the DSDP cruise investigations, Leg 42, in the Black Sea in 1972 (DSDP Volume XLII, Part 2), Olteanu (1978) and Benson (1978) briefly discussed the Pleistocene occurrence of ostracods in five of the recovered cores and provided linedrawing illustrations of some taxa. Many of the taxonomic determinations are tentative, based on very few specimens. Schornikov (1964, 1966a, b) has provided more detailed accounts of littoral ostracods from the northern Black Sea margins and Azov Sea (again with only line drawings), but there is little additional published data on Black Sea deep-water ostracods and still fewer SEM images.

\section{BLACK SEA CORES}

During the BlaSON (e.g. Popescu et al., 2001; Major et al., 2002) and ASSEMBLAGE (Lericolais et al., 2009) geophysical and coring research cruises, a number of short $(<2 \mathrm{~m})$ and longer $(<40 \mathrm{~m})$ sediment cores were recovered from the western region of the Black Sea. These cores yielded in situ ostracods in more than $95 \%$ of the 'pre-flood' samples examined and are, therefore, known to have been deposited under oxygenated bottom-water conditions. The autochthoneity of ostracod assemblages within such samples is generally confirmed through examination of the adult to juvenile ratio following the procedures outlined by Whatley (1983), recently reviewed by Boomer et al. (2003).

Little detailed autecological information is available for many of the species, despite their regional importance, with some species also occurring in the Caspian Sea. It is not yet possible to draw detailed palaeoenvironmental interpretations, such as quantitative salinity reconstructions, from the occurrence/absence of indicator species or assemblage composition. In the following sections we report on the changing composition of ostracod assemblages from five short cores on the NW Black Sea shelf collected by the BlaSON Cruise in 1998 (cores BLKS-9804, 9807, 9808, 9810, 9811) and for a longer core (MD04-2754) collected from the French R/V Marion Dufresne during the ASSEMBLAGE cruise of 2004 (Table 1).

\section{BLKS cores}

The BLKS cores are gravity cores, collected on a transect extending out across the Danube delta fan (Fig. 1)) during the BlaSON research cruise onboard the IFREMER R/V Le Suroit. The cores encompass depths that are still within the oxic zone through to those that are within the dysaerobic zone today. Although some of the cores penetrated to more than $5 \mathrm{~m}$ sediment depth (e.g. BLKS-9810), this paper will focus on the most recent sediments from each core. It is clear from the

\begin{tabular}{lcccc}
\hline Core & $\begin{array}{c}\text { Latitude } \\
(\mathrm{N})\end{array}$ & $\begin{array}{c}\text { Longitude } \\
(\mathrm{E})\end{array}$ & $\begin{array}{c}\text { Water depth } \\
(\mathrm{m})\end{array}$ & $\begin{array}{c}\text { Core length } \\
(\mathrm{cm})\end{array}$ \\
\hline BLKS-9804 & $44^{\circ} 12.02^{\prime}$ & $30^{\circ} 32.21^{\prime}$ & 101 & 81 \\
BLKS-9807 & $44^{\circ} 5.76^{\prime}$ & $30^{\circ} 46.81^{\prime}$ & 163 & 325 \\
BLKS-9808 & $4^{\circ} 5.47^{\prime}$ & $30^{\circ} 47.21^{\prime}$ & 186 & 370 \\
BLKS-9810 & $44^{\circ} 4.04^{\prime}$ & $30^{\circ} 50.68^{\prime}$ & 378 & 770 \\
BLKS-9811 & $44^{\circ} 3.02^{\prime}$ & $30^{\circ} 53.12^{\prime}$ & 500 & 757 \\
MD04-2754 & $41^{\circ} 59.23^{\prime}$ & $28^{\circ} 40.99^{\prime}$ & 453 & 3217 \\
\hline
\end{tabular}

Note that only the uppermost part of each core is discussed in the current paper.

Table 1. List of cores discussed in text with details of location, water depth and total core length.

changing lithologies and from the radiocarbon dating evidence that not all three sedimentary units are recorded in all of the cores (see details on Fig. 2); this is largely due to their depositional depth within the basin, the shallowest three sites, BLKS9804, 9807, 9808 never having experienced dysaerobia.

Equal volumes of sediment (approx 3-4 $\mathrm{cm}^{3}$ ) were subsampled from the cores, dried and disaggregated in $2 \%$ hydrogen peroxide for up to $2 \mathrm{~h}$ before washing through a $63 \mu \mathrm{m}$ sieve. The ostracods were totally picked and identified; the stratigraphical occurrence of the taxa is detailed on Figure 3. The range charts show that in the deeper parts of the basin, where the full sequence of units I, II and III are recorded (BLKS-9810, 9811), there is no post-sapropel 'recovery' as these sites are now within the dysaerobic zone. The few occasional occurrences are of juvenile valves, almost certainly transported from shallower depths.

Cores BLKS-9807 and 9808, recovered from the shelf edge, were the shallowest cores investigated in terms of their water depth. In these, only Unit III appears to be present (based on the lithology and ${ }^{14} \mathrm{C}$ dates in the former core), possibly a result of natural erosion, non-deposition due to changing water depth or problems during core recovery. These two shallow cores were never deep enough to develop the sapropel facies, while evidence from some of the pilot cores indicates that the very uppermost sediments (and sediment-water interface) have not necessarily been recovered from all cores. Discussion of the impact of changing sea-levels on the development and distribution of different sedimentary units during the late-glacial to early Holocene interval can be found in Lericolais et al. (2009).

Only four samples were available from the shallowest core (BLKS-9804), but they reveal in the upper few centimetres a switch from a pre-flood assemblage to one more typical of shallower depths, with elements, such as Hiltermannicythere rubra, that are more closely associated with the Mediterranean and Marmara (Nazik, 2001) seas today.

\section{Core MD04-2754}

This core was recovered during the ASSEMBLAGE research cruise onboard the French R/V Marion Dufresne during May 2004 as part of a sedimentary, geophysical and geochemical investigation of the western Black Sea. The core was recovered from a water depth of $453 \mathrm{~m}$ and was $32 \mathrm{~m}$ in total length. Only the uppermost $10 \mathrm{~m}$ were studied for ostracods (Fig. 4). Samples were prepared in a similar manner to those for the BLKS cores above. 


\section{Short cores from BLKS transect across the NW Black Sea shelf}

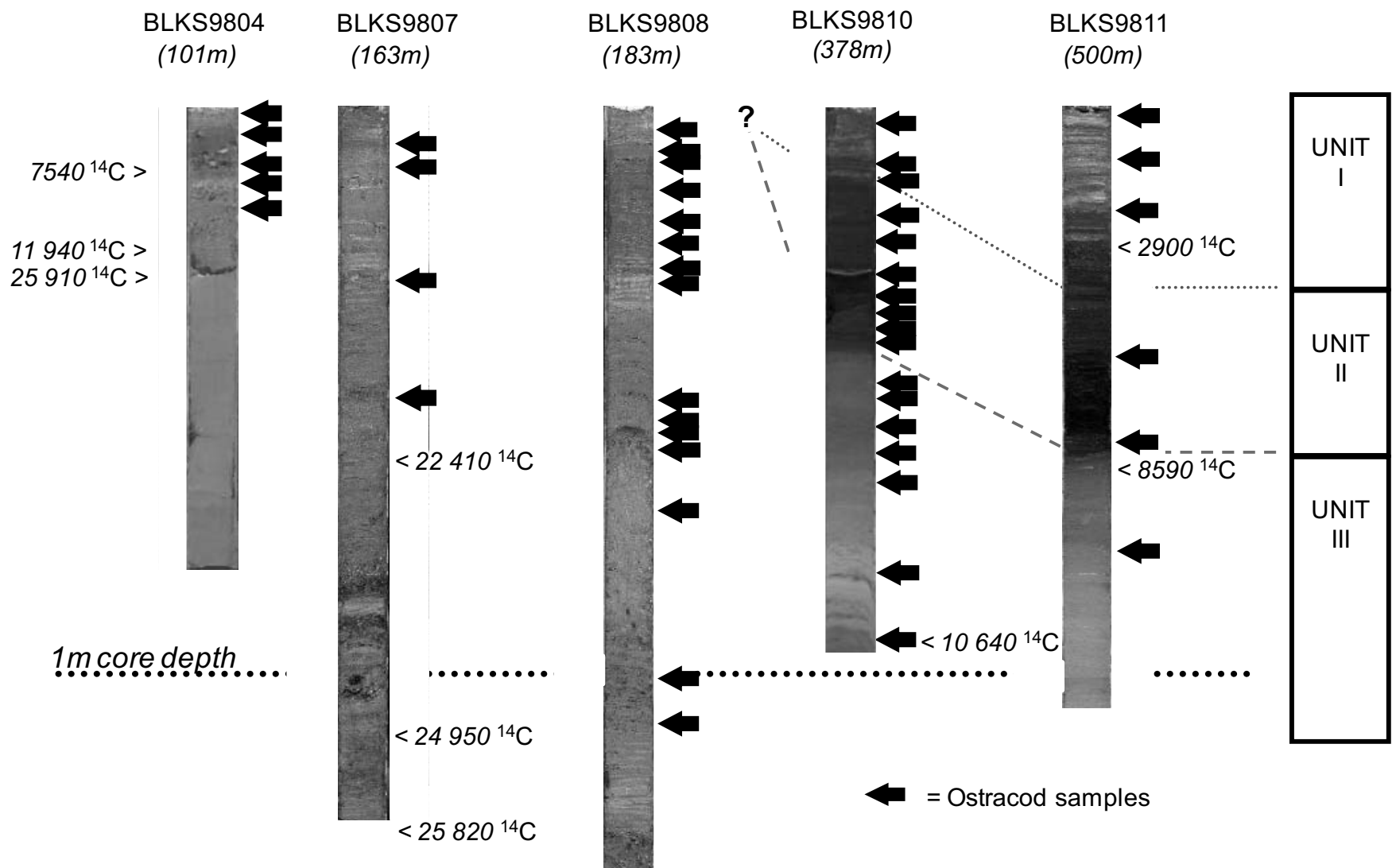

Fig. 2. Core photographs (approximately uppermost $1 \mathrm{~m}$ only), with indications of ostracod sampling levels and available uncalibrated radiocarbon dates. Sedimentary units discussed in text are noted on the right-hand side.

The core displays an uppermost unit of finely laminated sediments (0-230 cm, equivalent to Units I and II), below which is a relatively sharp transition into quite homogeneous grey clays. Thus, no distinct anoxic sediments are developed at this site prior to the deposition of the coccolith-rich laminae of Unit I. A number of ${ }^{14} \mathrm{C}$ dates are available from the core (Table 2) and indicate relatively continuous sedimentation from at least $20.5 \mathrm{ka}{ }^{14} \mathrm{C} \mathrm{BP}(c .970 \mathrm{~cm})$ to $5 \mathrm{ka}{ }^{14} \mathrm{C} \mathrm{BP}(c .154 \mathrm{~cm})$.

\section{FAUNAL RESPONSE}

The faunal records from the most of the BLKS cores are too short to make meaningful comments regarding their detailed response to changing environmental conditions within the Black Sea basin. The more extensive faunal record from MD04-2754 (Figs 4,5 ) suggests that the fauna can be subdivided into three distinct stratigraphical zones. The lowest zone (from the base of the sampled core up to about $430 \mathrm{~cm}$ ) comprises relatively diverse assemblages with equal proportions of Candonidae, Leptocytheridae and Loxoconchidae. At about $420 \mathrm{~cm}$ core depth there is a marked decrease in species diversity, with a change to assemblages dominated by the Candonidae (Fig. 5). This is associated with changes in the geochemical profile and a sharp rise in the carbonate content of the sediments. Comparison with the dated records of Kwiecien et al. (2008) suggests that this event at about $15 \mathrm{ka} \mathrm{BP}$ is associated with the first of a number of distinct melt-water pulses that discharged into the Black Sea basin from the Eurasian region.

The next major faunal event, at a core depth of about $230-240 \mathrm{~cm}$ coincides with a decrease in carbonate content and an increase in organic carbon content, both clearly associated with the development of the sapropel following early Holocene flooding. From this point onwards to the top of the core, ostracods are all but absent with only a few, probably allochthonous, records.

Notwithstanding the relatively short and incomplete records from the BLKS cores, the pattern of faunal change in the NW Black Sea basin is in broad agreement with the record from MD04-2754 in the SW Black Sea.

\section{TAXONOMY (BY IAN BOOMER)}

There are numerous taxonomic problems associated with Neogene to Recent ostracods from the Ponto-Caspian region. Many of the original publications referred to in the following pages, from the early to mid-twentieth century, were originally illustrated using only line drawings (or sketches); some key illustrations are often very small and of insufficient quality to assess the importance of particular features of outline or ornamentation. 


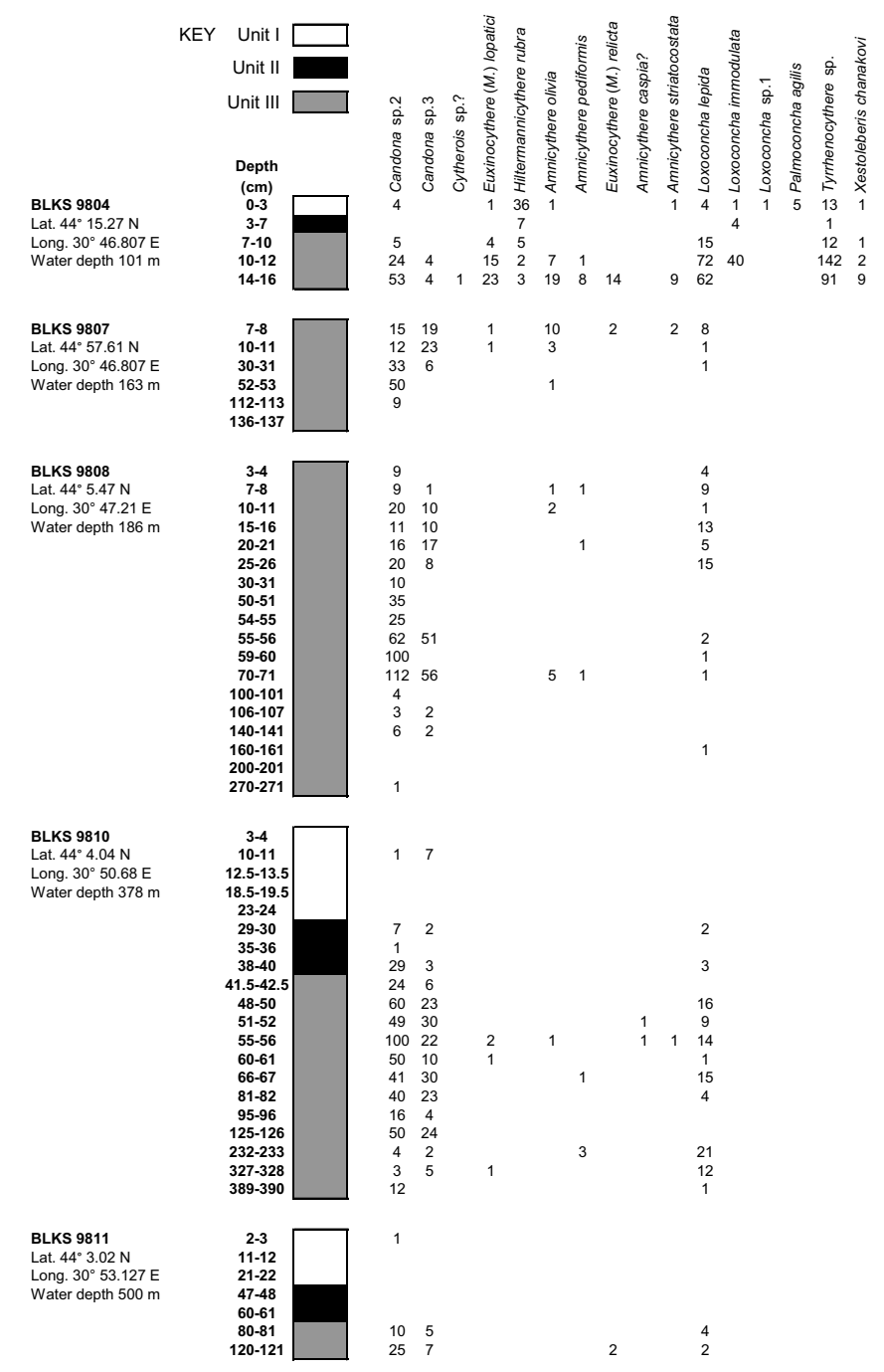

Fig. 3. Stratigraphical distribution of ostracod species in BLKS cores from the NW shelf of the Black Sea. Samples given as depths within core, too few ${ }^{14} \mathrm{C}$ dates are available to be certain of age determinations.

Researchers have often been led to rely on secondary illustrations by workers subsequent to the type designation (e.g. the plates of Agalarova et al. (1961) and Mandelstam et al. (1962) provide much more detailed illustrations for many of the taxa first described by Livental $(1929 ; 1938))$. There is a particular problem with so many closely related and morphologically similar taxa, further complicated by the evidence for polymorphism within some species (see Schornikov (1966b) for examples). Many new taxa described in those papers have been illustrated using only single specimens, while the location or status of some collections remains uncertain. Enquiries by the senior author and others (e.g. Gliozzi, Rome) with Russian colleagues have now ascertained that the collections of Livental (1929; 1938), formerly housed in Baku, are now lost (Malakhat Efendiyeva, Geological Institute, Baku, pers. comm.); the same is almost certainly true for the collections of Agalarova et al. (1961). Material figured by Suzin (1956) from the Miocene of the North Caucasus, formerly deposited in Grozny, must also be considered to be lost (Stepanova, Tesakova, pers. comms). The

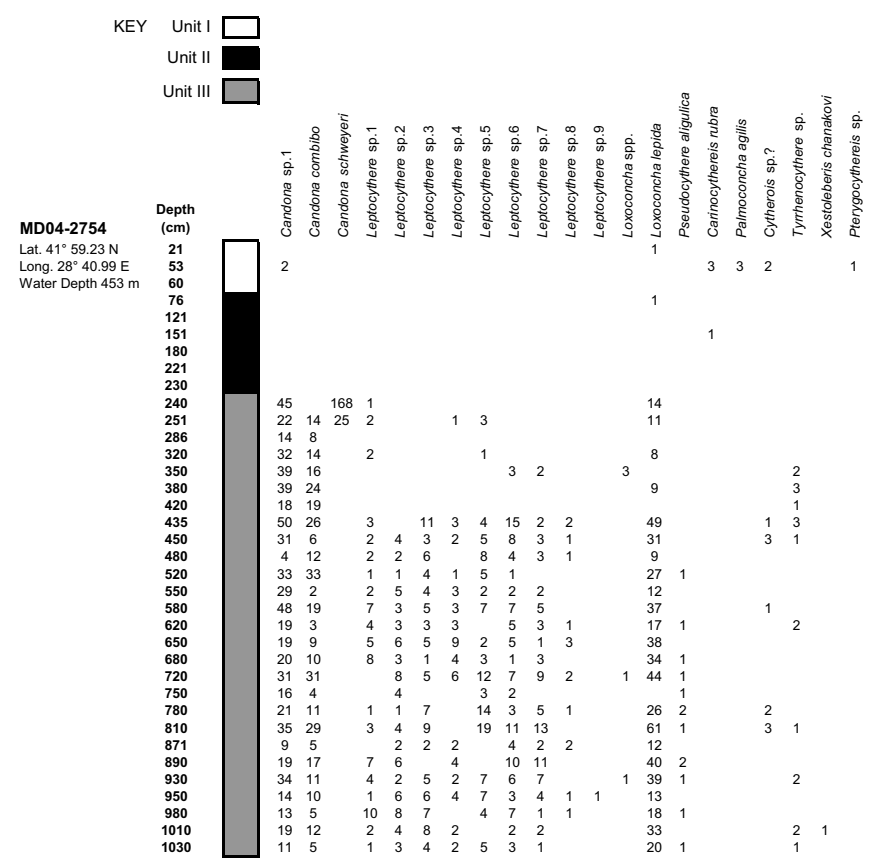

Fig. 4. Stratigraphical distribution of ostracod species in core MD042754. Samples given as depths within core; for discussion of chronology see text.

\begin{tabular}{lcc}
\hline Sample depth $(\mathrm{cm})$ & Code & ${ }^{14}$ C age $($ ka BP $)$ \\
\hline $153-155$ & FG-70 & $4750 \pm 30$ \\
$201-202$ & FG-69 & $5840 \pm 30$ \\
$234-235$ & FG-54 & $7420 \pm 40$ \\
$240-242$ & FG-55 & $9390 \pm 80$ \\
$378-380$ & FG-56 & $13020 \pm 120$ \\
$426-428$ & FG-57 & $16660 \pm 210$ \\
$970-971$ & FG-51 & $20450 \pm 60$ \\
\hline
\end{tabular}

Table 2. List of radiocarbon dates (uncalibrated) from core MD04-2754.

collections of Mandelstam et al. (1962) and Schweyer (1949) are all currently housed in the VNIGRI collections, St Petersburg.

Although Schornikov (1964; 1966a) has described soft-parts for some of the species mentioned herein, there are many that are known only from hard parts, yet may still be extant in the region; further collections are required to fill this knowledge gap.

The taxonomy section below considers some of the most abundant and some relatively minor but distinct elements of the assemblages encountered in the latest Pleistocene to Holocene sediments of the Black Sea. A more detailed and complete revision of the Ponto-Caspian fauna is undoubtedly required, together with full SEM and soft-part illustration where possible.

Class Ostracoda Latreille, 1806

Order Podocopida Sars, 1866

Suborder Cypridocopina Jones, 1901

Superfamily Cypridoidea Baird, 1845

Family Candonidae Kaufmann, 1900

Genus Candona Baird, 1845 


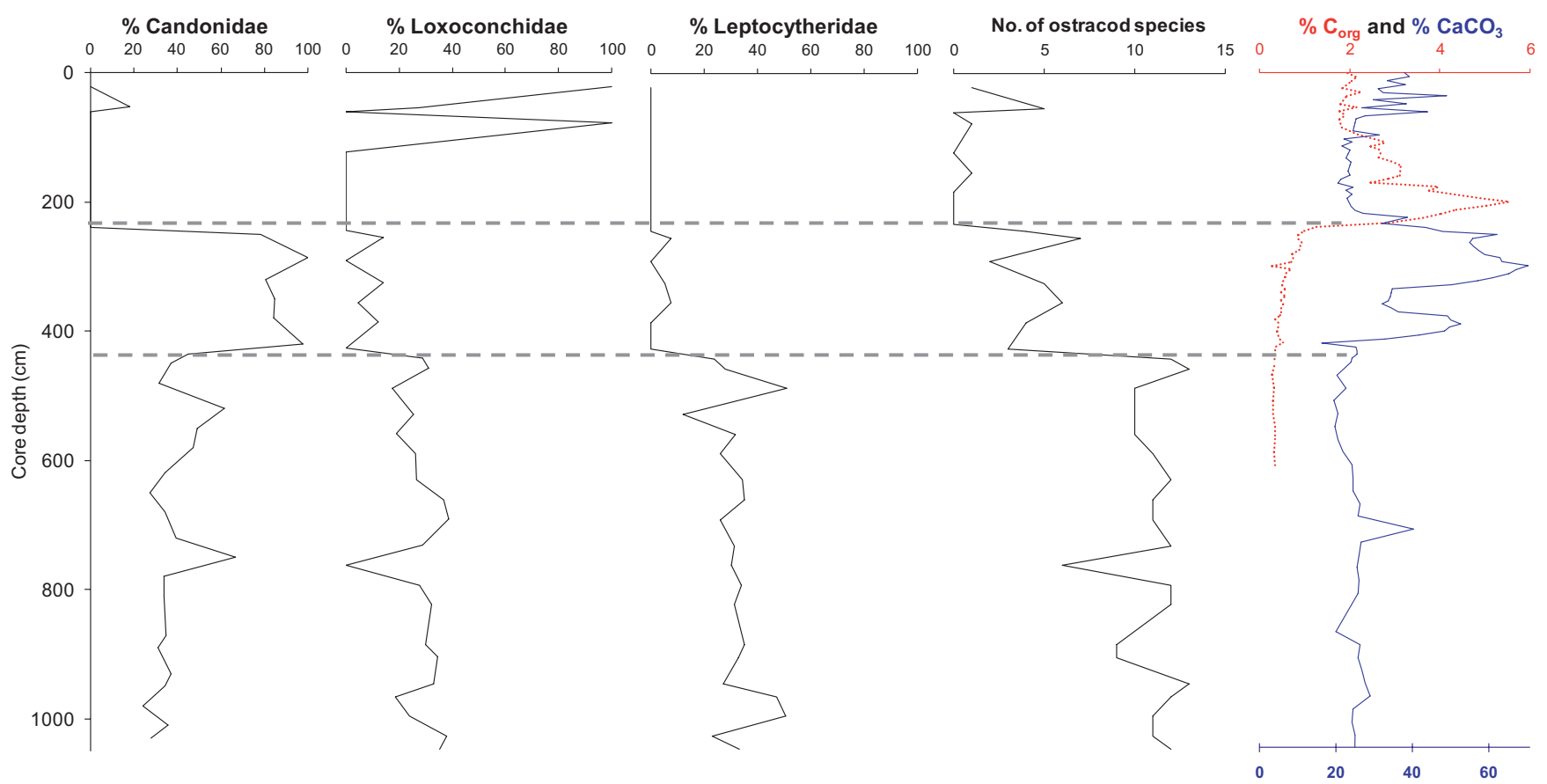

Fig. 5. Changing faunal composition, diversity and $\% \mathrm{CaCO}_{3} / \%$ organic carbon composition from core MD04-2754. Dashed lines indicate major faunal changes discussed in text.

Remarks. Many large, smooth-shelled species have been reported from Pleistocene to Recent sediments in the PontoCaspian region. For example, Agalarova et al. (1961) described almost 100 species that could tentatively be assigned to the Candonidae. A great number of these were referred to Candona but many other new genera were also established, e.g. Caspiella, Mandelstam, 1956 (often mis-spelt as Caspiolla) and Caspiocypris, Mandelstam, 1956. It is likely that many previously described species are true candonids/Candona but, in the absence of detailed soft-part information for the majority of taxa, this cannot be confirmed. The genus Candona is retained here until a more detailed review is undertaken.

\section{Candona schweyeri Schornikov, 1964}

(Pl. 1, fig. 7)

1949 Bythocypris elongata Schweyer: 62, pl. 4, figs 7-8.

1961 Candona elongata (Schweyer); Agalarova et al.: 60.

1962 Bythocypris elongata Schweyer; Mandelstam et al.: 138,

pl. 17, fig. 2.

1964 Candona schweyeri Schornikov: P1. 1, figs 1-13.

Remarks. Candona schweyeri was established by Schornikov (1964) as a nom. nov. for Bythocypris elongata Schweyer (1949), which he re-assigned to Candona. The bi-nomen $C$. elongata already being occupied, Schornikov (1964) stated that it was a younger homonym of C. elongata Herrick, 1879 and C. elongata Vávra, 1891, although that record should be recorded as Candona elongata Brady \& Norman, 1889 in Vávra, 1891 and is also a homonym of at least four further species (Kempf, pers. comm.). The species differs from the other large, smooth-shelled candonids encountered in the present study by the rather straight dorsal margin with a maximum height close to the posterior. Schornikov (1964) recorded this species from deltas of the Black and Azov Sea basins. He described this and the other taxa he discussed as having 'Caspian origins', having been recorded in the late Neogene deposits of the southern parts of what was then the USSR.

Candona sp. 1

(P1. 1, figs 1-3, 8)

?1929 Candona Abichi Livental: 51, pl. 2, figs 34-37. (Note that Livental (1929) capitalized the species names of some of the newly described taxa in this 1929 publication.)

?1961 Candona abichi Livental; Agalarova et al.: 59, pl. 35, fig. $1 \mathrm{a}-\mathrm{b}$.

?1961 Candona combibo Livental; Agalarova et al.: 58, pl. 31, fig. 1a-b, pl. 32, fig. 1a-b, pl. 33, fig. 4a-b.

?1962 Candona abichi Livental; Mandelstam et al.: 28, pl. 13, figs 7-9.

Remarks. This species is difficult to assign to an established taxon due to the hand-drawn nature of many type figures and the lack of soft-parts. The species outwardly resembles the $C$. candida group of Eurasian species but has a distinctly rounded postero-dorsal margin in lateral view. This is the most abundant species encountered in this work and almost certainly has been recorded in other studies, although probably under a range of different names. It perhaps most closely resembles the illustrations of C. abichi Livental, as figured by Mandelstam et al. (1962, pl. 13, figs 7-9). However, the type figures are somewhat less convincing, given the suggestion of a more distinct posteroventral angularity. The specimen figured by Agalarova et al. (1961) as C. abichi is unlikely to be conspecific. Caspiocypris lyrata (Livental) in Agalarova et al., pl. 4, figs 1-3 is a similar 


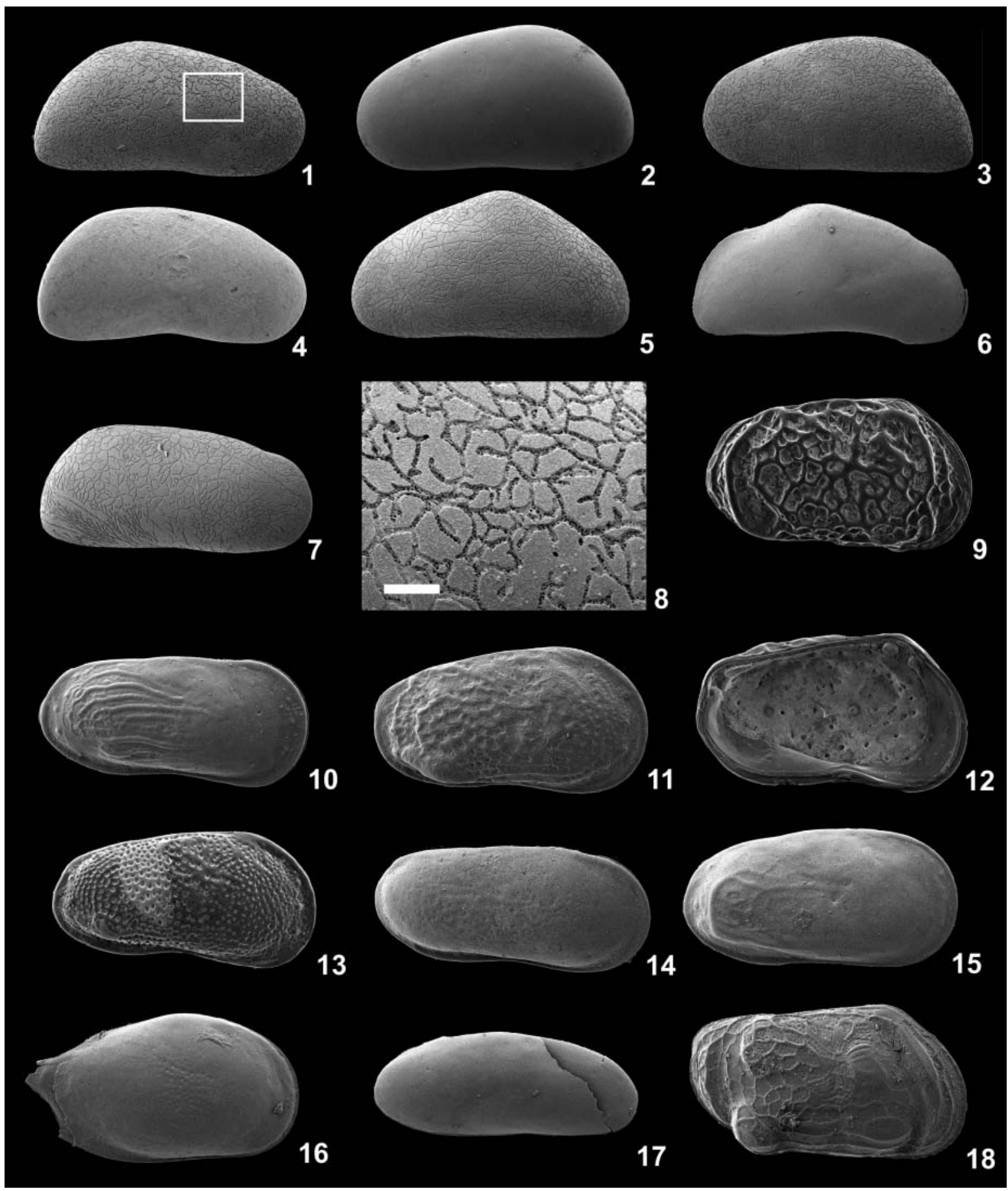

Explanation of Plate 1.

All specimens adult, external lateral views unless otherwise stated. figs 1-3, 8. Candona sp. 1: 1, RV (OS 16854) $\times 39$, specimen shows bacterial or algal 'micro-crazing', MD04-2754, $350 \mathrm{~cm} ; 2$, LV (OS 16855) × 36, MD04-2754, $350 \mathrm{~cm}$; 3, LV (OS 16856) $\times 38$, specimen shows bacterial or algal 'micro-crazing', MD04-2754, $550 \mathrm{~cm} ; \mathbf{8}$, detail of micro-crazing on (1) approx $\times 500$, scale bar $5 \mu \mathrm{m}$. fig. 4. Candona sp. 2, RV (OS 16857) $\times 39$, BLKS-9804 10-12 cm. figs 5-6. Candona sp. 3: 5, LV (OS 16858) × 38, specimen shows bacterial or algal 'micro-crazing', MD04-2754, 890 cm; 6, RV $($ OS 16859) $\times$ 34, MD04-2754, $650 \mathrm{~cm}$. fig. 7. Candona schweyeri Schornikov, 1964, RV (OS 16860) × 42, MD04-2754, $240 \mathrm{~cm}$. figs 9, 12. Euxinocythere (Maeotocythere) lopatici (Schornikov, 1964) n. comb., BLKS-9804, 0-3 cm: 9, RV (OS 16861) × 80; 12, LV internal lateral (OS 16862$) \times 80$. fig. 10. Amnicythere striatocostata (Schweyer, 1949) Stancheva, 1990, RV (OS 16863) $\times 78$, MD04-2754, $650 \mathrm{~cm}$. fig. 11. Euxinocythere (Maeotocythere) relicta (Schornikov, 1964) n. comb., RV (OS 16864) × 90, MD04-2754, 650 cm. fig. 13. Amnicythere pediformis (Schornikov, 1966) Tarasov, 1996, RV (OS $16865) \times 77$, BLKS-9804, 14-16 cm. fig. 14. Amnicythere propinqua (Livental, 1929) Stancheva, 1968, RV (OS 16866) $\times 100$, MD04-2754, 950 cm. fig. 15. Amnicythere caspia? (Livental, 1930 nomen nudum), RV (OS 16867) $\times 90$, MD04-2754, $650 \mathrm{~cm}$. fig. 16. Pseudocythere aligulica? (Stepanaitys, 1962) n. comb., RV (OS 16868) × 96, MD04-2754, $1030 \mathrm{~cm}$. fig. 17. Cytherois sp.? RV (OS 16869, specimen now broken anteriorly) $\times$ 97, MD04-2754, $450 \mathrm{~cm}$. fig. 18. Amnicythere bendovanica (Livental, 1935) n. comb., RV, probably A-1 (OS 16870) × 80, MD04-2754, $950 \mathrm{~cm}$. 

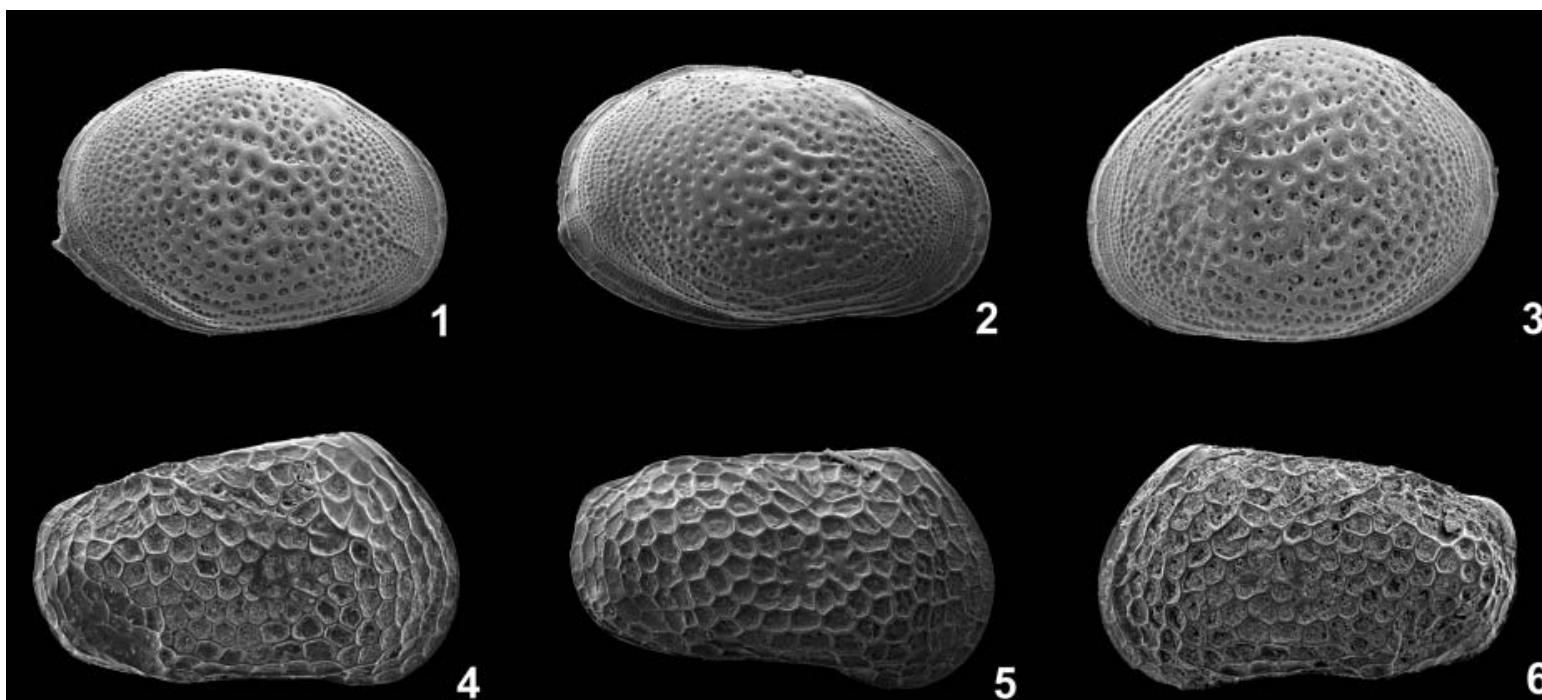

5

6
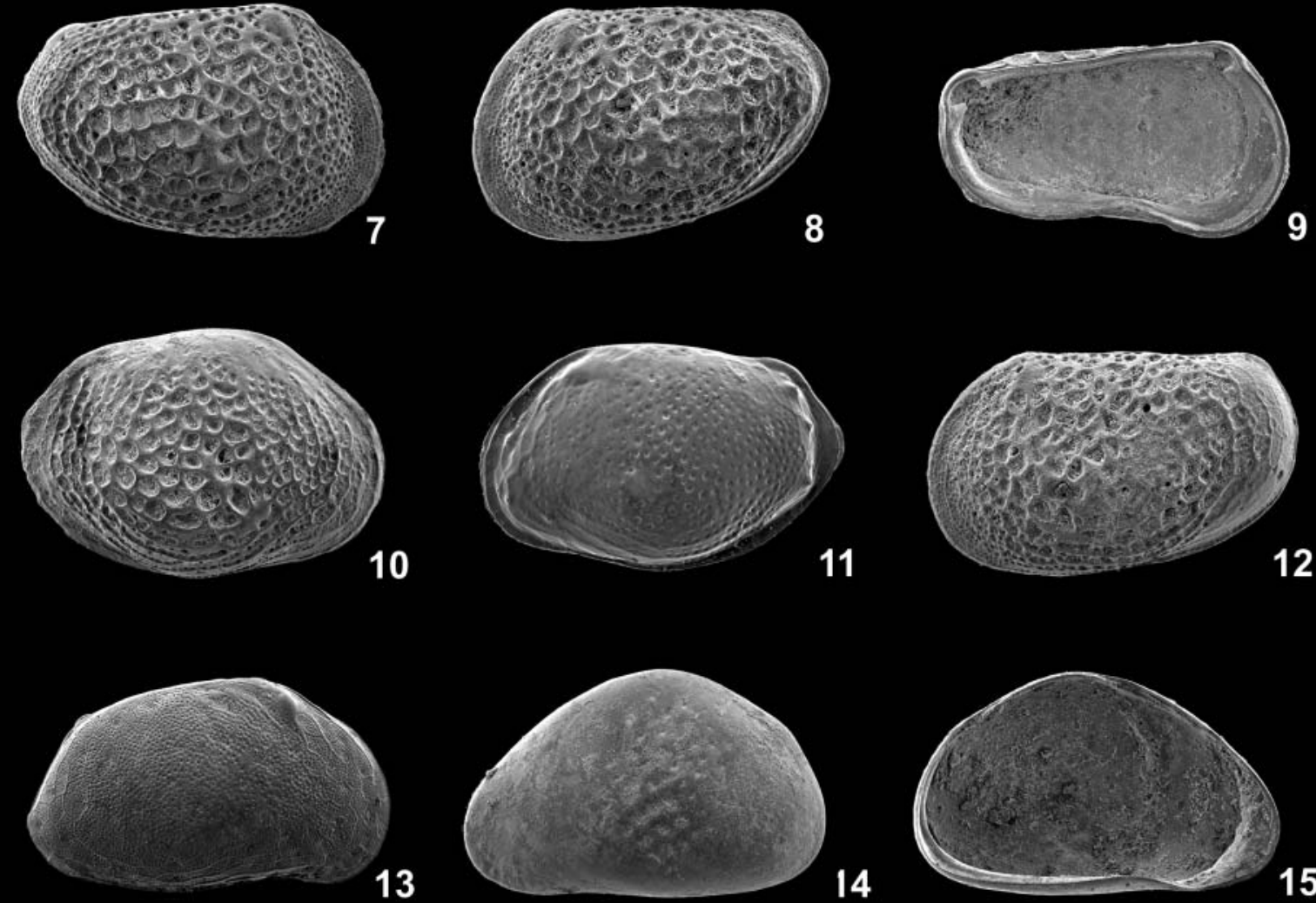

Explanation of Plate 2.

All specimens adult, external lateral views unless otherwise stated. figs 1-3. Loxoconcha lepida Stepanaitys, 1962: 1, RV female (OS 16871) $\times$ 60, BLKS-9804, 10-12 cm; 2, RV male (OS 16872) × 60, MD04-2754, $350 \mathrm{~cm} ; \mathbf{3}$, LV female (OS 16873) × 65, BLKS-9804, 10-12 cm. figs 4-6, 9. Amnicythere olivia (Livental, 1938) Stancheva, 1968, all BLKS-9804, 10-12 cm except (5): 4, RV female (OS 16874) $\times 68 ; 5$, RV male (OS $16875) \times 68$, MD04-2754, $350 \mathrm{~cm} ; \mathbf{6}$, LV female $(\mathrm{OS} \mathrm{16876)} \times 66$; 9, LV male internal (OS 16877) $\times$ 69. figs 7-8, 12. Loxoconcha immodulata Stepanaitys, 1958, BLKS-9804, 0-3 cm: 7, RV female (OS 16878) × 82; 8, LV female (OS 16879) $\times$ 75; 12, LV male (OS 16880) $\times$ 72. fig. 10 Loxoconcha sp. 1, RV (OS 16881) × 69, BLKS-9804, 0-3 cm. fig. 11. Palmoconcha agilis (Ruggieri, 1967) Ruggieri, 1992, LV (OS 16882) $\times$ 68, BLKS-9804, 0-3 cm. fig. 13. Tyrrhenocythere sp., RV (OS 16883) $\times 39$, BLKS-9804, 10-12 cm. figs 14-15. Xestoleberis chanakovi Livental, in Agalarova et al., 1961, BLKS-9804, 10-12 cm: 14, LV (OS 16884) $\times 57$; 15, LV internal (OS 16885) $\times 61$ showing Xestoleberis 'spot'. 
species for which, although designated as a Livental species, no record can be found of its original description and the Agalarova et al. publication appears to be the only such description and designation of the species. This appears to be a not uncommon situation.

Some of the candonid valves recovered in this work have clear evidence of 'microbial' borings (c.5 $5 \mathrm{~m}$ scale) on the external surfaces of the valves (Pl. 1, fig. 8). These have not yet been encountered on the internal surfaces, leading to the conclusion that they represent ante mortem damage.

\section{Candona sp. 2}

$$
\text { (Pl. 1, fig. 4) }
$$

2008 Candona schweyeri Schornikov; Opreanu: 61, fig. 10.

Remarks. Similar to Candona sp. 1 but with a more broadlyrounded posterior margin, flatter dorsal and more incurved ventral margin in the right valve. This species dominates candonid assemblages from the NW Black Sea, being commonly recorded in the BLKS cores but apparently absent from the SW Black Sea (MD04-2754). For now, the two appear to be geographically mutually exclusive but, given the similarity of the two taxa, further discrimination may later prove their co-occurrence in some samples. The more northern distribution for Candona sp. 2 is further supported by the only other published record, that of a right valve figured by Opreanu (2008) from the Romanian sector of the Black Sea.

\section{Candona sp. 3}

(Pl. 1, figs 5-6)

?1949 Bythocypris sp. n. Schweyer: 64, pl. 3, fig. 8 .

Remarks. A distinct, large and fragile species with a triangular dorsal margin in lateral outline and an 'over-hanging' anteroventral margin. Many authors have figured candonid species with a high dorsal arch, giving a strongly 'triangular' aspect in lateral view. The illustrated right valve ( $\mathrm{Pl}$. 1, fig. 6) is an adult, but the left valve is an A-1 instar. No intact adult left valves of this species have been recovered so far. Its closest affinities would appear to be with the left valve of Bythocypris sp. n. figured by Schweyer (1949). Agalarova et al. (1961) illustrate species, such as C. cavis 'Mandelstam in litt.' (p. 59, pl. 35, fig. 4), which appear morphologically similar to the illustrated left valve of the current species. So far only recorded from the NW Black Sea.

\section{Suborder Cytherocopina Gründel, 1967 \\ Superfamily Cytheroidea Baird, 1850 \\ Family Leptocytheridae Hanai, 1957}

Remarks. The majority of small cytheroidean taxa encountered in Pleistocene-Recent sediments from the Ponto-Caspian region can be assigned to the Leptocytheridae. Gliozzi et al. (2005) reviewed the Neogene brackish-water leptocytherids from southern Europe, summarizing the major morphological traits and generic assignments. They discussed a number of leptocytherid genera and subgenera; of these, Amnicythere, Euxinocythere
(Euxinocythere) and E. (Maeotocythere) are represented in the present material. The genus Leptocythere sensu stricto is probably not present within these assemblages.

Amnicythere was originally erected as a subgenus of Leptocythere (Devoto, 1965) to distinguish leptocytherid species from the Pleistocene of Italy which had both branching and simple anterior marginal pore canals (AMPCs), the presence of a snap pit/knob (a simple closed-carapace 'locking' system along the inner ventral margin) and secondary ornamentation (the latter being clearly more of a specific difference and one that is not uncommon within Leptocythere). Stancheva (1968) later emended the diagnosis, noting also the different structure of the hinge and raised it to generic rank. As Gliozzi et al. (2005) note, the genus appears to have radiated within the Neogene of eastern Paratethys and constitutes a major component of PontoCaspian assemblages.

Stancheva (1968) also erected a new genus Euxinocythere and two subgenera E. (Euxinocythere) and E. (Maeotocythere) within the Leptocytheridae, both of which have recent representatives in the Ponto-Caspian region. The three genera are most easily distinguished on their lateral outline and hingement. Amnicythere species are typically elongate (similar externally to Leptocythere sensu stricto) but possess rather simple and slender hinges with smooth median elements (in left valve), with perhaps only a weak anterior thickening. In contrast, species assigned to both subgenera of Euxinocythere are often more quadrate in lateral outline, E. (Euxinocythere) particularly so. The median and terminal hinge elements are much more robust than is the case for Amnicythere. In E. (Euxinocythere), the median element becomes expanded anteriorly into a series of toothlets that increase in size terminally. In E. (Maeotocythere) this pattern is repeated at both the anterior and posterior extremities of the median element, in this genus the posterior tooth and socket are often found immediately at the rather sharp postero-cardinal angle and the elements may be curved across this apex. Both subgenera of Euxinocythere are often more heavily calcified than species of Amnicythere examined to date.

Genus Amnicythere Devoto, 1965 (emend. Stancheva, 1968)

Amnicythere bendovanica (Livental, 1935) n. comb.

(Pl. 1, fig. 18)

?1935 Cythere bendovanica Livental: details unknown

1940 Cythere bendovanica Livental; Agalarova et al.: 46, pl. 2, fig. 3.

1961 Leptocythere bendovanica (Livental); Agalarova et al.: 125, pl. 72, figs 5-6.

1962 Leptocythere bendovanica (Livental); Mandelstam et al:: 235, pl. 38 , fig. 5 .

Remarks. A distinctive, small to medium-sized, rather quadrate, species, with two weak swellings or tubercles postero-ventrally and postero-dorsally. Strong lateral ribs parallel both the anterior and posterior margins. Both Agalarova et al. (1961) and Mandelstam et al. (1962) figure a species which they refer to this species, putting it into synonymy with Cythere bendovanica Livental of Agalarova et al. (1940). Both ascribe original species authorship to Livental but neither give a publication year nor 
full authorship citation. Agalarova et al. (1940), however, synonymizes it with Cythere bendovanica 'Livental, 1935' (without further detail); the current author has not been able to obtain that source and it is not referenced by any other subsequent publications. It is possible that this was an unpublished report and the name may therefore be a nomen nudum. The figured specimen in this work (Pl. 1, fig. 18) is an A-1 instar. Adults appear rare, none has been recovered intact, but seem broadly similar to the late instars. Based on the observed internal features the species is probably best accommodated within Amnicythere.

\section{Amnicythere caspia? (Livental, 1930 nomen nudum)}

$$
\text { (P1. 1, fig. 15) }
$$

?1930 Cythere caspia Livental: details unknown.

?1938 Cythere caspia Livental: 62, P1. 1, figs 20-22.

1961 Leptocythere caspia Livental; Agalarova et al.: 108, pl. 63, figs 4-6.

1962 Leptocythere hilda Stepanaitys; in Mandelstam et al.: 252, pl. 40 , fig. 15 .

Remarks. A species with a recurved or C-shaped rib on the postero-lateral surface, broadly paralleling the posterior margin, although more angular than that margin. The rib, which is particularly strongest/inflated at its postero-ventral extent, marks the posterior termination of the lateral surface; there may be weak secondary ribbing/reticulation within the posterior third of the valve.

No 1930 publications by this author can be traced and, although it is mentioned in the synonymy list for this species by Agalarova et al. (1961), it does not appear in their references. The same publication date is given in the synonymy of Cythere caspia by Livental (1938), together with an abbreviated reference which is noted as being 'рукопись', i.e. 'a manuscript'. Again the full title does not appear in the reference list and it must be assumed, therefore, that the species is currently a nomen nudum.

Livental's drawings (1938; p. 62, Pl. 1, figs 20-22) depict a distinctly laterally-compressed carapace which may be a slight exaggeration. The specimens observed in the current study are certainly not as inflated as most of the other leptocytherid taxa encountered but are not as obviously compressed as those he figures. As with other species considered here, a number of other published illustrations may depict the same, or closely related species (e.g. Leptocythere spectabilis (Markova) in Mandelstam et al., 1962, p. 108, pl. 34 fig. 5a-b). The material figured by Agalarova et al. (1961) and the fragment illustrated as L. hilda by Mandelstam et al. (1962) are almost certainly conspecific.

\section{Amnicythere olivia (Livental, 1938) Stancheva, 1968} (pl. 2,figs 4-6, 9)

1938 Cythere olivia Livental: 62, P1. 1, figs 27-29.

?1949 Cythere ergeniensis Schweyer: 34, pl. 8, figs 4, 6. ?1956 Leptocythere olivina Livental; Agalarova: 106, pl. 11, fig. 32.

1962 Cythere olivina Livental in Mandelstam et al.: 194, pl. 30, figs 9-10, pl. 35, fig. 12 .
1978 Leptocythere ergeniensis (Schweyer); Olteanu: pl. 4, fig 1, pl. 5, fig 3 .

2008 Amnicythere olivina (Livental); Opreanu: 59, fig. 5.

Remarks. In 1938 Livental described Cythere olivia from the Pleistocene of the Baku region. Agalarova et al. (1961) later referred to Leptocythere olivina (Livental), giving the correct page and figures numbers of the Livental (1938) species in synonymy, thereby introducing a spelling error that may have been perpetuated (see Mandelstam et al. (1962) and Agalarova (1956) for examples). It is possible, however, that the two are distinct species. Subsequently, in Mandelstam et al. (1962) a new species from the Pleistocene of Turkmenistan is designated as Leptocythere olivina Livental (designated as sole author); no other taxa are referred to in synonymy but the present author (IB) believes this also to be the same species. Although all the illustrated type specimens are line drawings, the present author believes them to be conspecific with L. olivia. In view of the arrangement of the hingement particularly, this species is best accommodated within the genus Amnicythere. Stancheva (1968), in her review of the family Leptocytheridae, placed both $L$. olivina (Livental) (sic.) and the similar L. palimpsesta (Livental, 1929 ) in the present genus.

The species belongs to a group of morphologically similar taxa that occur in the Pleistocene and Holocene deposits of both the Black and Caspian Sea (see Leptocythere sp. 9, Boomer et al. (2005, Pl. 1, fig. 11) for Caspian example). Many of these related species are commonly referred to either the present species or to Leptocythere palimpsesta (Livental, 1929).

The current species is probably related to a number of closely related taxa originally described by Livental in 1929 (see, particularly, Limnicythere nitida, p. 37, pl. 2, figs 3-4 and Cythere fragilis, Pl. 1, figs 1-2). In both Mandelstam et al. (1962) and Agalarova et al. (1961), the descriptions of L. olivina mention similarities to Leptocythere andrussovi (Livental) from which it differs 'by the absence of two protuberances in the posterior'. Note that this species was also mis-spelt, having originally been designated as Cythere andrusovi Livental. Again, without the original Livental material, the taxonomic status of many of these taxa remains uncertain.

The specimen figured by Opreanu (2008, p. 59, fig. 5), which she cites incorrectly as Amnicythere olivina (Livental, 1929), is almost certainly con-specific (a male left valve), coming from late Quaternary sediments in the Romanian coastal sector of the Black Sea. Olteanu (1978), in his reconnaissance of ostracods from the DSDP cruise, illustrated line drawings of a species, Leptocythere ergeniensis (Svejer) [=Schweyer], which also resembles the present material, although not the original illustration by Schweyer (1949).

Amnicythere pediformis (Schornikov, 1966) Tarasov, 1996 (P1. 1, fig. 13)

1966a Leptocythere pediformis Schornikov: 33, pl. 2, figs 1-13. 1996 Amnicythere pediformis (Schornikov); Tarasov: 853.

2005 Leptocythere sp. 2 Boomer et al.: Pl. 1, fig. 13.

Remarks. An elongate species with moderately straight dorsal and slightly sinuous ventral margins converging slightly 
posteriorly. Key external ornament consists of fine, regular punctation, slightly coarser in the postero-lateral region and decreasing in size towards all margins. Although this species may well have been recorded by previous authors (e.g. Leptocythere saluta Livental, pl. 55, fig. 3 in Agalarova et al., 1961), only the figures by Schornikov can be included here with any confidence, given the lack of any other useful morphological characteristics. The species also occurs in contemporaneous deposits within the Caspian Sea (Boomer et al., 2005).

\section{Amnicythere propinqua (Livental, 1929) Stancheva, 1968}

(Pl. 1, fig. 14)

1929 Cythere propinqua Livental: 20, Pl. 1, figs 21-24.

Remarks. From the original illustrations this appears to be a relatively unornamented taxon, elongate with evenly rounded anterior and posterior margins. As such, there are few key characteristics on which to base specific identification with any certainty. Similar unornamented species are not uncommon in the literature and the species is also thought to occur in the Caspian Sea (author's unpublished information). Schornikov (1966b) suggested that Leptocythere propinqua (Livental) was a smooth variant of Leptocythere cymbula (Livental) but the current author believes the two are distinct species.

Amnicythere striatocostata (Schweyer, 1949) Stancheva, 1990 (Pl. 1, fig. 10)

1949 Cythere striatocostata Schweyer: 27-28, pl. 9, fig. 8.

1961 Leptocythere striatocostata (Schweyer); Agalarova et al.: 108, pl. 63, figs 1-3a, b.

1962 Leptocythere striatocostata Mandelstam et al.: 138, pl. 41, fig. 17.

1964 Leptocythere striatocostata (Schweyer); Schornikov: 1284, pl. 6, figs 1-15.

2008 Amnicythere striatocostata (Schweyer); Opreanu: 58, fig. 1.

Remarks. There are a number of related taxa in the literature which appear to share the features of the present material (e.g. Leptocythere cornutocostata Schweyer in Mandelstam et al., 1962, pl. 37, fig. 11, but not the type figure of that species). An elongate leptocytherid carapace with generally weak, longitudinal ribs along the postero-lateral flanks that may extend anteriorly. Schornikov (1964) illustrated some of the morphological variability observed within this species. Other related genera are known from the Caspian Sea (Boomer, unpublished data). It is possible that many of the figured specimens assigned to this taxon represent more than one species.

Genus Euxinocythere Stancheva, 1968

Subgenus Euxinocythere (Maeotocythere) Stancheva, 1968

Euxinocythere (Maeotocythere) lopatici (Schornikov, 1964) n. comb.

(P1. 1, figs 9, 12)

?1929 Cythere Bosqueti Livental: 24, Pl. 1, fig. 27.

?1949 Cythere bosqueti Livental; Schweyer: 25, pl. 9, fig. 7.
?1961 Leptocythere postrugosa Agalarova in Agalarova et al.: 83, pl. 49, figs 5-6.

?1962 Leptocythere bosqueti (Livental); Mandelstam et al.: 225, pl. 36, figs 8-11.

1964 Leptocythere lopatici Schornikov: 1279, pl. 2, figs 1-7, pl. 3, figs $1-11$.

2008 Euxinocythere lopatici (Schornikov); Opreanu: 60, fig. 7.

Remarks. A rather distinctive species, although some variation in the degree and position of ribbing and reticulation patterns can be observed within the present material and between Black Sea and Caspian assemblages (IB, unpublished data). The species is broadly similar to that described as Cythere bosqueti by Livental (1929); despite the simplistic illustration of a single valve, it is distinctive and must at least be closely related. Many authors have subsequently illustrated similar specimens, see synonymy list above. L. bosqueti (Livental), illustrated by Olteanu (1978, pl. 4, fig. 2), has much reduced central reticulation but must also be closely related.

Schornikov (1964) described Leptocythere lopatici from the Azov-Black Sea region, discriminating it from the similar $L$. bosqueti by the degree and positioning of the ornament. It is possible, however, that this is intra-specific variation and that L. lopatici Schornikov, and possibly L. postrugosa Agalarova, are junior synonyms of $L$. bosqueti. The present material is referred to L. lopatici, as the illustrations are so similar to the present material that no comparison can be made with the types of L. bosqueti. Some of the specimens recovered within the current project have yielded evidence of a thick exocuticle still in place, which has the apparent effect of reducing the degree of reticulation on the external surface of the carapace. A similar effect is seen on the specimen illustrated by Opreanu (2008).

$$
\begin{gathered}
\text { Euxinocythere (Maeotocythere) relicta (Schornikov, 1964) n. } \\
\text { comb. } \\
\text { (Pl. 1, fig. 11) }
\end{gathered}
$$

1964 Leptocythere relicta Schornikov: 1282. pl. 4, figs 1-9, pl. 5, figs 1-9.

2008 Euxinocythere lopatici Schornikov; Opreanu: 60, fig. 7.

Remarks. Schornikov (1964) described three new species of Leptocythere from the deltas flowing into the Azov-Black Sea basin; one of these (L. relicta) illustrates an elongate leptocytherid with rather regularly spaced, shallow reticulae which may vary in strength and distribution across the lateral faces. Similarly, there is variation in the morphology of the postero-lateral surface where the reticulation grades into short ribs/elongate nodes and the postero-ventral margin of the lateral surface may be variable in its form and position. The hingement observed on the current species is a little more robust than on the original drawings but, given the variability in the type description, these are not considered significant enough to warrant specific separation.

Family Loxoconchidae Sars, 1925

Genus Loxoxoncha Sars, 1866

Loxoconcha lepida Stepanaitys, 1962

(pl. 2, figs 1-3) 
1962 Loxoconcha lepida Stepanaitys in Mandelstam et al.: 178, pl. 28 , fig. 7.

1962 Loxoconcha unodensa Mandelstam in Mandelstam et al:: 178, pl. 28, fig. 9 .

1964 Loxoconcha lepida Stepanaitys; Schornikov: 1290, pl. 11, figs $1-12$.

2008 Loxoconcha lepida Stepanaitys; Opreanu: 61, fig. 9.

Remarks. A common, strongly dimorphic species with distinctive circular arrangement of reticulae that fine towards all margins. Schornikov (1964) recorded living specimens of $L$. lepida (Stepanaitys) from deltas in the Azov-Black Sea basin. He also synonymized the species with L. unodensa described in the same original publication (Mandelstam et al., 1962), where a male and a female valve were described as separate species. This species also occurs in the Caspian Sea.

\section{Loxoconcha immodulata Stepanaitys, 1958}

$$
\text { (pl. 2, figs 7, 8, 12) }
$$

1958 Loxoconcha immodulata Stepanaitys: 19, Pl. 1, fig. 18.

1962 Loxoconcha immodulata Stepanaitys; Mandelstam et al.: 175, pl. 28, fig. 2.

1974 Loxoconcha immodulata Stepanaitys; MorduchaiBoltovsky: 199, fig. 172.

1996 Loxoconcha immodulata Stepanaitys; Boomer et al:: 81, P1. 1, fig. 18.

Remarks. A reticulate species of Loxoconcha with marked sexual dimorphism, distinguished by having a marked eye-spot, triangular lateral outline in females and quadrate outline in males, which have much reduced ornament in the central to posterodorsal region of the lateral surfaces. The species described as $L$. immodulata Stepanaitys, 1958 from the Black Sea and figured by Morduchai-Boltovsky (1974) and Boomer et al. (1996) from the Aral Sea have much weaker development of the primary reticulation, but this is probably an environmental or eco-phenotypic effect. This species is also present in the Caspian Sea. The year of publication for this species was given erroneously as 1962 by Boomer et al. (1996) and Faranda et al. (2007). Faranda et al. (2007) place L. immodulata in Loxoconchissa (Loxocaspia). The current author does not consider the generic and subgeneric diagnoses to be distinct from Loxoconcha and has retained this generic assignment.

\section{Loxoconcha sp. 1}

(pl. 2, fig. 10)

Remarks. A species with ventro-lateral extension or overhang, reticulation is coarsest in the mid-valve area, fining towards the margins. Many similar taxa are illustrated within Agalarova et al. (1961) and Mandelstam et al. (1962) but at this stage it is not possible to be certain of their synonymy. The Black Sea samples include a number of rare loxoconchid species.

Genus Palmoconcha Swain \& Gilby, 1974

Palmoconcha agilis (Ruggieri, 1967) Ruggieri, 1992

(pl. 2, fig. 11)
1967 Loxoconcha agilis Ruggieri; 377, pl. 37, fig. 6, text-figs $442-446$

1975 Loxoconcha aff. L. agilis Ruggieri; Bonaduce et al.: 102, pl. 65, figs 9-14.

Remarks. A loxoconchid whose general carapace features and presence of a smooth median hinge element places it within Palmoconcha. Originally described from the late Miocene of Italy, this apparently long-ranging species occurs in the Late Holocene sediments of the Black Sea, in relatively shallow waters. The species forms part of the 'Mediterranean' fauna (together with taxa such as Hiltermannicythere rubra), which has become established in the 'post-connection' period. The species bears a strong resemblance to the specimens figured by Bonaduce et al. (1975) as Loxoconcha aff. L. agilis from the Recent sediments of the Adriatic Sea. The species was also recorded by a number of authors from the Marmara and Black seas (e.g. Nazik, 2001; Ongan et al., 2009).

Family Trachyleberididae Sylvester-Bradley, 1948 Genus Tyrrhenocythere Ruggieri, 1955

Tyrrhenocythere $\mathrm{sp}$. (pl. 2, fig. 13)

Remarks. There are a number of species of Tyrrhenocythere described from Pleistocene to Recent sediments in the eastern Mediterranean and Ponto-Caspian region. Specific differentiation is difficult due to the great similarity in lateral outline of different but closely related species (and/or the occurrence of polymorphy; Schornikov, 1981), strong sexual dimorphism in most species (the figured specimen is a male) and lack of significant distinguishing external characteristics. Although originally derived from marginal marine ancestors (Pipik, 2007), the genus is known to occur in continental water bodies throughout the Ponto-Caspian region, including the Aral Sea (Boomer et al., 1996) and Caspian Sea (Athersuch, pers. comm.).

Family Bythocytheridae Sars, 1866

Genus Pseudocythere Sars, 1866

Pseudocythere aligulica? (Stepanaitys, 1962) n. comb.

(Pl. 1, fig. 16)

?1962 Cytherura aligulica Stepanaitys in Mandelstam et al.: 182, pl. 28, fig. 15 .

Remarks. Stepanaitys (in Mandelstam et al., 1962) figured a single valve of this new species with a remarkably similar lateral outline to the present material, although it lacks the distinctive postero-ventral spine seen in most species of Pseudocythere and has some ornament in the central valve area. The present species has only weakly developed central reticulation but may well be conspecific.

Family Paradoxostomatidae Brady \& Norman 1889 Genus Cytherois G.W. Müller, 1884

Cytherois sp.?

(Pl. 1, fig. 17) 
Remarks. A rather small, thinly calcified species which is only tentatively assigned to this genus based on its external lateral outline, lack of ornamentation and common occurrence in brackish-water habitats across much of NW Europe together with the Loxoconchidae and Leptocytheridae, as here. No internal features were observed due to the fragile nature of the specimens. Occurs in many samples but often no more than 1-2 specimens are found.

\section{Family Xestoleberididae Sars, 1928}

Xestoleberis chanakovi Livental, in Agalarova et al., 1961 (pl. 2, figs 14-15)

?1949 Xestoleberis sp. Schweyer: 51, pl. 11, fig. 6.

1961 Xestoleberis chanakovi Livental; Agalarova et al.: 156, pl. 93, figs 5, pl. 96, figs 1-4.

1962 Xestoleberis chanackovi (sic.) Livental; Mandelstam et al.: 183, pl. 28, fig. 16.

Remarks. A relatively large, highly-arched species of Xestoleberis with distinct mid-lateral, shallow punctation present on all valves, best developed in late instars and adults. Recorded by both Agalarova et al. (1961) and Mandelstam et al. (1962) as a Livental species, but neither give a date of publication. Mandelstam et al. (1962) apparently spelt the name chanackovi incorrectly, although the two may be distinct species. The original description for this species cannot be found amongst Livental's publications. As the first published record, that of Agalarova et al. may have priority but, for now, it should be considered a nomen nudum. Of those specimens figured in Agalarova et al. (1961), perhaps those best fitting the present material are those on plate 96 (figs 3-4), where the lateral outline and shallow development of just a small, central area of ornamentation are similar. Schweyer (1949) figured a species from the Pliocene of the Caucasus-Volga region (incorrectly cited as 1948 by Mandelstam et al., 1962), which bears a strong similarity to the present species in lateral outline but no evidence of mid-valve pitting is seen in the illustration.

Atay \& Tunoğlu (2002) refer to Xestoleberis (Xestoleberis) chanakovi Stancheva, probably in error, in their comments for two species (Xestoleberis sp. 2 and X. sp. 3) from middle-late Pannonian sediments around the Çanakkale Bridge. No further taxonomic or literature details are given and the illustrated specimens are too poorly preserved to be certain of their affinities. Olteanu (2006) refers to Pontoleberis chanakovi (Livental) in a table of species occurrences from the Gurian (Early Pleistocene) of the Ponto-Caspian basin, but no specimens are illustrated.

\section{DISCUSSION}

Boomer et al. (2005) noted that the Ponto-Caspian fauna has its origins in the Paratethyan sea of the late Neogene and reflects the remnants of a low-brackish-water fauna, adapting to salinity changes and isolation. The assemblages described here have clear affinities with those described in numerous studies of late Neogene to Recent ostracods from the former Soviet Union, Eastern Europe and eastern Mediterranean regions. The late Quaternary and Holocene assemblages for the Black and
Caspian seas share common taxa which can be traced back to late Pliocene-Pleistocene periods when the two were connected. Since separation, the two have also established additional, endemic components. The Aral Sea is much shallower and is geologically very young compared to the Black and Caspian seas. The low diversity Aral Sea ostracod fauna (Boomer et al., 1996) is, therefore, relatively recently established, derived largely from elements of the Black and Caspian Sea fauna and it lacks a distinctive endemic component.

From the faunal evidence presented, it is clear that the ostracod response to major hydrological events in the Black Sea is reflected in changing diversity, abundance and assemblage composition throughout the late glacial to Holocene interval.

In this paper we have highlighted some of the taxonomic problems of the Ponto-Caspian ostracod fauna. These problems concern both common and rare taxa and must be addressed if future palaeoenvironmental interpretations (both faunal and geochemical) based on ostracods from this region are to be compared meaningfully. A full taxonomic revision of the PontoCaspian ostracod fauna is required.

\section{ACKNOWLEGEMENTS}

The authors thank all participants of BlaSON (1998, IFREMER/GeoEcoMar bilateral project) and ASSEMBLAGE (2004, EU-funded project EVK3-CT-2002-00090) for their assistance during these cruises and the support of LSCE, CNRS, IFREMER and IPEV during this research. In particular, IB thanks Claudia Strechie (GeoEcoMar, Bucharest) for providing material and data from the BlaSON cruise. IB acknowledges the support of a Leverhulme Trust award during this research (F/00 $125 / \mathrm{G}$ ). John Athersuch (Stratadata, UK) and Elsa Gliozzi (Rome) are thanked for their many discussions on PontoCaspian ostracods and commenting on an earlier draft of this paper. Anna Stepanova and Ekaterina Tesakova (Moscow) are also thanked for assistance during writing.

\section{Manuscript received 10 July 2010 \\ Manuscript accepted 29 July 2010}

Scientific editing by Alan Lord

\section{REFERENCES}

Agalarova, D.A. 1956. Microfauna of the productive beds of Azerbaijan and the red-beds of Turkemenistan. Izvestiya Akademia Nauk Turkmenistan SSR, 88-125, pls 5-16.

Agalarova, D.A., Dzhafarov, D.I. \& Khalilov, D.M. 1940. Spravocknik po Mikofaune tretichniykh otlozheniy Apsheronskogo poluostrova. Azerbaijan State Publisher, Baku, 135 pp. [In Russian].

Agalarova, D.A., Kadyrova, Z.K. \& Kulieva, S.A. 1961. Ostracoda from Pliocene and Post-Pliocene deposits of Azerbaijan. Azerbaijan State Publisher, Baku, 420 pp. [In Russian].

Aksu, A.E., Hiscott, R.N., Mudie, P.J., Rochon, A., Kaminski, M.A., Abrajano, T. \& Yasar, D. 2002. Persistent Holocene outflow from the Black Sea to the eastern Mediterranean contradicts Noah's Flood Hypothesis. GSA Today, 12: 4-10.

Atay, G. \& Tunoğlu, C. 2002, Ostracod fauna and their bioprovince of the Kilitbahir drilling samples (Eceabat/Çanakkale). Yerbilimleri, 26: 119-130. [In Turkish].

Bahr, A., Lamy, F., Arz, H., Kuhlmann, H. \& Wefer, G. 2005. Late glacial to Holocene climate and sedimentation history in the NW Black Sea. Marine Geology, 214: 309-322. 
Bahr, A., Arz, H.W., Lamy, F. \& Wefer, G. 2006. Late glacial to Holocene paleoenvironmental evolution of the Black Sea, reconstructed with stable oxygen isotope records obtained on ostracod shells. Earth and Planetary Science Letters, 241: 863-875.

Ballard, R.D., Coleman, D.F. \& Rosenberg, G.D. 2000. Further evidence of abrupt Holocene drowning of the Black Sea shelf. Marine Geology, 170: 253-261.

Benson, R.H. 1978. Preliminary examinations of the Ostracodes of DSDP Leg 42B. In: Usher, J.L. \& Supko, P. (Eds), Initial Reports of the Deep-Sea Drilling Project, 42(2): 1039-1040.

Bonaduce, G., Ciampo, G. \& Masoli, M. 1975. Distribution of Ostracoda in the Adriatic Sea. Pubblicazione Stazione Zoologica di Napoli, 40: $1-304$.

Boomer, I., Whatley, R.C. \& Aladin, N. 1996. Aral Sea Ostracoda as environmental indicators. Lethaia, 29: 77-85.

Boomer, I., Horne, D.J. \& Slipper, I. 2003. The use of Ostracodes in Paleoenvironmental Studies, or What can you do with an ostracod shell? Paleontological Society Papers, 9: 153-180.

Boomer, I., von Grafenstein, U., Guichard, F. \& Bieda, S. 2005. Modern and Holocene sublittoral ostracod assemblages (Crustacea) from the Caspian Sea: A unique brackish, deep-water environment. Palaeogeography, Palaeoclimatology, Palaeoecology, 225: 173-186.

Devoto, G. 1965. Lacustrine Pleistocene in the lower Liri Valley (southern Latium). Geologica Romana, 4: 291-368.

Faranda, C., Gliozzi, E. \& Ligios, S. 2007. Late Miocene brackish Loxoconchidae (Crustacea, Ostracoda) from Italy. Geobios, 40: 303324.

Fontugne, M., Guichard, F., Bentaleb, I., Strechie, C. \& Lericolais, G. 2009. Variations in ${ }^{14} \mathrm{C}$ reservoir ages of Black Sea waters and sedimentary organic carbon during anoxic periods: Influence of photosynthetic versus chemoautotrophic production. Radiocarbon, 51: 969-976.

Giosan, L., Filip, F. \& Constantinescu, S. 2009. Rapid Communication: Was the Black Sea catastrophically flooded in the early Holocene? Quaternary Science Reviews, 28: 1-6.

Giunta, S., Morigi, C., Negri, A., Guichard, F. \& Lericolais, G. 2007. Holocene biostratigraphy and paleoenvironmental changes in the Black Sea based on calcareous nannoplankton, Marine Micropaleontology, 63: 91-110.

Gliozzi, E., Rodriguez-Lazaro, J., Nachite, D., Martin-Rubio, M. \& Bekkali, R. 2005. An overview of Neogene brackish leptocytherids from Italy and Spain: biochronological and palaeogeographical implications. Palaeogeography, Palaeoclimatology, Palaeoecology, 225: 283-301.

Herrick, C.L. 1879. Microscopic Entomostraca. Annual Report of the Geological and Natural History Survey of Minnesota, 7(for 1878): 81-123 (Ostracoda: 110-113).

Kaminski, M.A., Aksu, A.E., Box, M., Hiscott, R.N., Filipescu, S. \& Al-Salameen, M. 2002. Late Glacial to Holocene benthic foraminifera in the Marmara Sea: implications for Black Sea-Mediterranean Sea connections following the last deglaciation. Marine Geology, 190: 165-202.

Kwiecien, O., Arz, H.W., Lamy, F., Wulf, S., Bahr, A., Röhl, U. \& Haug, G. 2008. Estimated reservoir ages of the Black Sea since the last Glacial. Radiocarbon, 50: 99-118.

Lericolais, G., Bulois, C., Gillet, H. \& Guichard, F. 2009. High frequency sea level fluctuations recorded in the Black Sea since the LGM. Global and Planetary Change, 66: 65-75.

Livental, V.E. 1929. Ostracoda of Akchagilian and Apsheronian beds of the Babazan Section. Izvestiya Azerbajdzahnskogo Politekhnischeskogo Instituta, 1: 1-58. [In Russian].

Livental, V.E. 1935. Ostracoda of the Apsheronian levels. Archive of the Azerbaijan Scientific Research Institute (AzNII). [No further details available].

Livental, V.E. 1938. Deposits and microfauna of the Baku area. Azerbaijan Scientific Research Institute for Petroleum, Transactions, 1 46-67. [In Russian].

Major, C.O., Ryan, W.B.F., Lericolais, G. \& Hajdas, I. 2002. Constraints on Black Sea outflow to the Sea of Marmara during the last glacial-interglacial transition. Marine Geology, 190: 19-34.
Major, C.O., Goldstein, S.L., Ryan, W.B.F., Lericolais, G., Piotrowski, A.M. \& Hajdas, I. 2006. The co-evolution of Black Sea level and composition through the last deglaciation and its paleoclimatic significance. Quaternary Science Reviews, 25: 2031-2047.

Mandelstam, M.I. 1956. Order Ostracoda. In: Mandelstam, M.I., Shneyder, G.F. \& Zanina, J.E. (Eds), New families and genera. All-Union Scientific Research, Geological Institute, Moscow (VSEGEI), 12: 87-144. [In Russian].

Mandelstam, M.I., Markova, L., Rosyeva, T. \& Stepanaitys, N. 1962. Ostracoda of the Pliocene and post-Pliocene deposits of Turkmenistan. Turkmenistan Geological Institute, Ashkhabad, 288 pp.

Morduchai-Boltovsky, F.D. 1974. Atlas of Invertebrates of the Aral Sea. Pishchevaya Promyshlennost, Moscow, 272 pp. [In Russian].

Nazik, A. 2001. Ostracode faunas of bottom sediments from the continental shelf, south Marmara Sea, NW Turkey, and their comparison with other shelf environments in the Mediterranean and Aegean regions. Geological Journal, 36: 111-123.

Neretin, L.N., Volkov, I.I., Böttcher, M.E. \& Grinenko, V.A. 2001. A sulfur budget for the Black Sea anoxic zone. Deep-Sea Research I, 48: 2569-2593.

Oaie, G. \& Melinte-Dobrinescu, M.C. 2009. Holocene litho- and biostratigraphy of the NW Black Sea (Romanian shelf). Quaternary International, doi: 10.1016/j.quaint.2009.12.014.

Olteanu, R. 1978. Ostracoda from DSDP Leg 42B. In: Usher, J.L. \& Supko, P. (Eds), Initial Reports of the Deep-Sea Drilling Project, 42(2): $1017-1038$.

Olteanu, R. 2006. Paleoecologia ecosistemelor salmastre din Bazinul Dacic Evoluţia paleogeografică şi paleoecologică al arealului CarpatoPonto-Caspic in intervalul Miocen-Recent. Ecosisteme fosile Paleoecologia ecosistemelor salmastre din Bazinul Dacic. GeoEcoMar, Bucarest, 90 pp. [In Romanian].

Ongan, D., Algan, O., Kapan-Yesilyurt, S., Nazik, A., Ergin, M. \& Eastoe, C. 2009. Benthic faunal assemblages of the Holocene sediments from the Southwest Black Sea shelf. Turkish Journal of Earth Sciences, 18: 239-297.

Opreanu, P.A. 2008. Ostracode relicte Ponto-Caspice in sectorul Romanecs Aal Marii Negre. GeoEcoMarina, 14(Suppl. 1): 57-62.

Pipik, R. 2007. Phylogeny, palaeoecology, and invasion of non-marine waters by the late Miocene hemicytherid ostracod Tyrrhenocythere from Lake Pannon. Acta Palaeontologica Polonica, 52: 351-368.

Popescu, I., Lericolais, G., Panin, N., Wong, H.K. \& Droz, L. 2001. Late Quaternary channel avulsions on the Danube deep-sea fan. Marine Geology, 173: 25-37.

Ross, D.A., Degens, E.T. \& Macllvaine, J. 1970. Black Sea: recent sedimentary history. Science, 170: 163-165.

Ruggieri, G. 1967. Due ostracofaune del Miocene alloctono della Val Marecchia. Rivista Italiana di Paleontologia e Stratigrafia, 73: 351384.

Ryan, W. \& Pitman, W. 1999. Noah's Flood: The New Scientific Discoveries About the Event That Changed History. Simon \& Schuster, New York, 337 pp.

Ryan, W.B.F., Pitman, W.C., Major, C.O. et al. 1997. An abrupt drowning of the Black Sea shelf. Marine Geology, 138: 119-126.

Ryan, W.B.F., Major, C.O., Lericolais, G. \& Goldstein, S.L. 2003. Catastrophic Flooding of the Black Sea. Annual Review of Earth and Planetary Sciences, 31: 525-554.

Schornikov, E.I. 1964. An experiment on the distinction of the Caspian elements of the ostracod fauna in the Azov-Black Sea Basin. Zoologicheski Zhurnal, 43: 1276-1293.

Schornikov, E.I. 1966a. Leptocythere (Crustacea, Ostracoda) of the Azov-Black Sea Basin. Zoologicheski Zhurnal, 45: 32-49.

Schornikov, E.I. 1966b. Sexual dimorphism and shell variation in Leptocythere. In: Vyalov, O.S. (Ed.), First All Union Symposium on Fossil Ostracoda, Kiev, 217 pp.

Schornikov, E.I. 1981. Tyrrhenocythere amnicola (Crustacea): a polytypic ostracod species from the Cainozoic of southern USSR. In: Bragina, L.F. (Ed.), Biostratigraphy of the Recent and Neogene of the South West USSR, 107-122. Moldavian Academy of Sciences, Kishinev. [In Russian].

Schrader, H.J. 1979. Quaternary paleoclimatology of the Black Sea basin. Sedimentary Geology, 23:165-180. 
Schweyer, A.V. 1949. On the Pliocene Ostracoda of the Northern Caucases and Lower Volga Region. With some new data on the systematics of fossil ostracods. Trudy Vesoyuznogo Neftyanogo Nauchno-Isseldovatelskogo Geologo-Razvedochnogo Instituta (VNIGRI), New Series, 30: 9-68.

Sergeeva, N.G. 2003. Meiobenthos of deep-water anoxic hydrogen sulphide zone of the Black Sea. In: Yimaz, A. (Ed.) Proceedings of the 2nd International Conference on Oceanography of the eastern Mediterranean and Black Sea: similarities and differences of two interconnected basins, 880-887. Tubitak, Ankara.

Shcherbakov, F.A. \& Babak, Y.V. 1979. Stratigraphic subdivision of the Neoeuxinian deposits in the Black Sea. Oceanology, 19: 298-300.

Siani, G., Paterne, M., Arnold, M., Bard, E., Metivier, B., Tisnerat, N. \& Bassinot, F. 2000. Radiocarbon Reservoir Ages in the Mediterranean Sea and Black Sea. Radiocarbon, 42: 271-280.

Siddall, M., Pratt, L.J., Helfrich, K.R. \& Giosan, L. 2004. Testing the physical oceanographic implications of the suggested sudden Black Sea infill 8400 years ago. Paleoceanography, 19: PA1024.

Stancheva, M. 1968. New data on the subfamily Leptocytherinae Hanai, 1957. Bulgarian Academy of Sciences, Sofia, Bulletin of the Geological Institute, 17: 37-48.
Stancheva, M. 1990. Upper Miocene ostracods from Northern Bulgaria. Geologica Balcanica, 5: 1-116.

Stepanaitys, N.E. 1958. New forms of ostracods from the Bakunian deposits of western Turkmenistan. Izvestiya Akademia Nauk Turkmenistan SSR, 2: 11-20.

Suzin, A.V. 1956. Ostracoda from Tertiary deposits of the North Caucasus. Gostoptekhizdat, Moscow, 191 pp. [In Russian].

Tarasov, A.G. 1996. New records of benthic invertebrates in deep waters of the Caspian Sea. Zoological Journal, 75: 848-856. [In Russian, with English summary].

Uchupi, E. \& Ross, D. 2000. Early Holocene marine flooding of the Black Sea. Quaternary Research, 54: 68-71.

Vávra, W. 1891. Monographie der Ostracoden Böhmens. Archiv der naturwissenschaftlichen Landesdurchforschung von Böhmen. 8: 1-116.

Whatley, R.C. 1983. Some simple procedures for enhancing the use of Ostracoda in palaeoenvironmental analysis. Norwegian Petroleum Directorate, Bulletin, 2: 129-146.

Yanko-Hombach, V., Gilbert, A.S. \& Dolukhanov, P. 2007. Controversy over the great flood hypotheses in the Black Sea in light of geological, paleontological, and archaeological evidence. Quaternary International, 167-168: 91-113. 


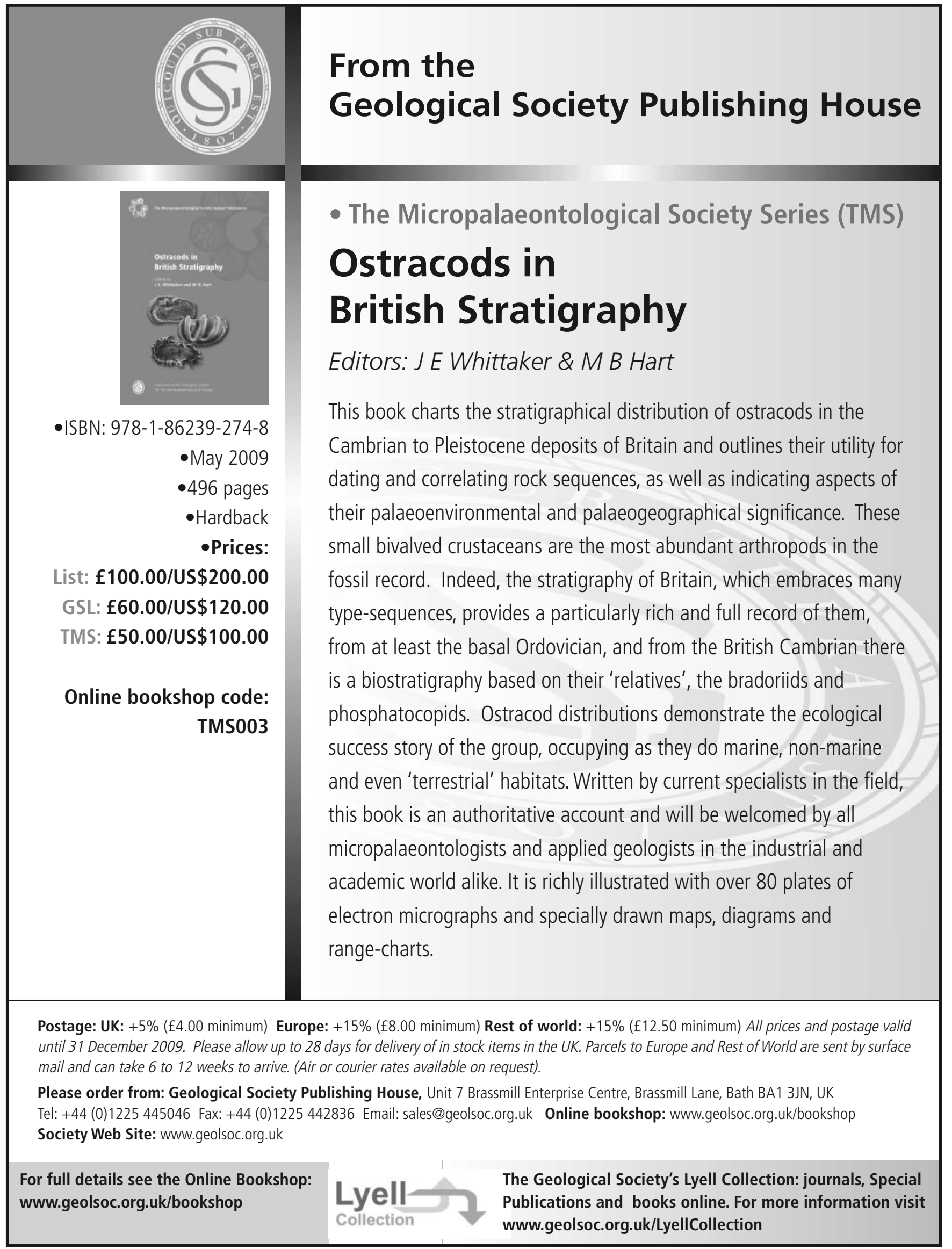

